\title{
RESULTS FROM THE INDEPENDENT SAMPLING AND ANALYSIS OF USED OIL AT THE IMPACT SERVICES FACILITY IN OAK RIDGE, TENNESSEE
}

David A. King, CHP, PMP

Prepared for the

U.S. Department of Energy

Office of Environmental Management

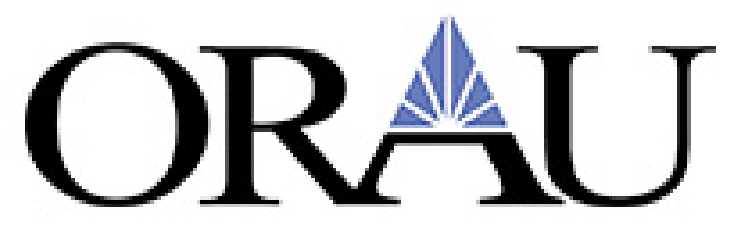

Approved for public release; further dissemination unlimited. 
ORAU provides innovative scientific and technical solutions to advance research and education, protect public health and the environment and strengthen national security. Through specialized teams of experts, unique laboratory capabilities and access to a consortium of more than 100 major Ph.D.-granting institutions, ORAU works with federal, state, local and commercial customers to advance national priorities and serve the public interest. A 501(c)(3) nonprofit corporation and federal contractor, ORAU manages the Oak Ridge Institute for Science and Education (ORISE) for the U.S. Department of Energy (DOE). Learn more about ORAU at www.orau.org.

\section{NOTICES}

The opinions expressed herein do not necessarily reflect the opinions of the sponsoring institutions of Oak Ridge Associated Universities.

This report was prepared as an account of work sponsored by the United States Government. Neither the United States Government nor the U.S. Department of Energy, nor any of their employees, makes any warranty, expressed or implied, or assumes any legal liability or responsibility for the accuracy, completeness, or usefulness of any information, apparatus, product, or process disclosed, or represents that its use would not infringe on privately owned rights. Reference herein to any specific commercial product, process, or service by trade name, mark, manufacturer, or otherwise, does not necessarily constitute or imply its endorsement or recommendation, or favor by the U.S. Government or any agency thereof. The views and opinions of authors expressed herein do not necessarily state or reflect those of the U.S. Government or any agency thereof. 


\title{
RESULTS FROM THE INDEPENDENT SAMPLING AND ANALYSIS OF USED OIL AT THE IMPACT SERVICES FACILITY IN OAK RIDGE, TENNESSEE
}

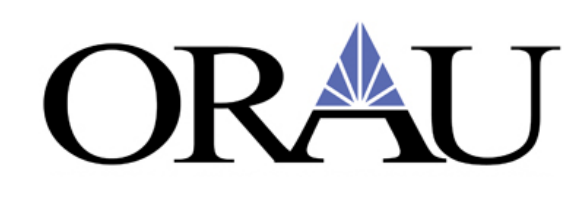

\author{
Prepared by \\ David A. King, CHP, PMP \\ Independent Environmental Assessment and Verification Program \\ Oak Ridge Associated Universities \\ Oak Ridge Institute for Science and Education
}

FINAL REPORT

APRIL 2013

Prepared for the

U.S. Department of Energy

Office of Environmental Management

Prepared by Oak Ridge Associated Universities under the Oak Ridge Institute for Science and Education contract, number DE-AC05-06OR23100, with the U.S. Department of Energy. 
THIS PAGE INTENTIONALLY LEFT BLANK 


\section{APPROVALS}

\section{RESULTS FROM THE INDEPENDENT SAMPLING AND ANALYSIS OF USED OIL AT THE IMPACT SERVICES FACILITY IN \\ OAK RIDGE, TENNESSEE}

APRIL 2013

\section{Prepared by:}

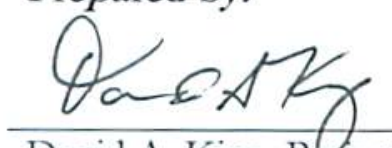

David A. King, Pfoject Manager

Oak Ridge Associated Universities
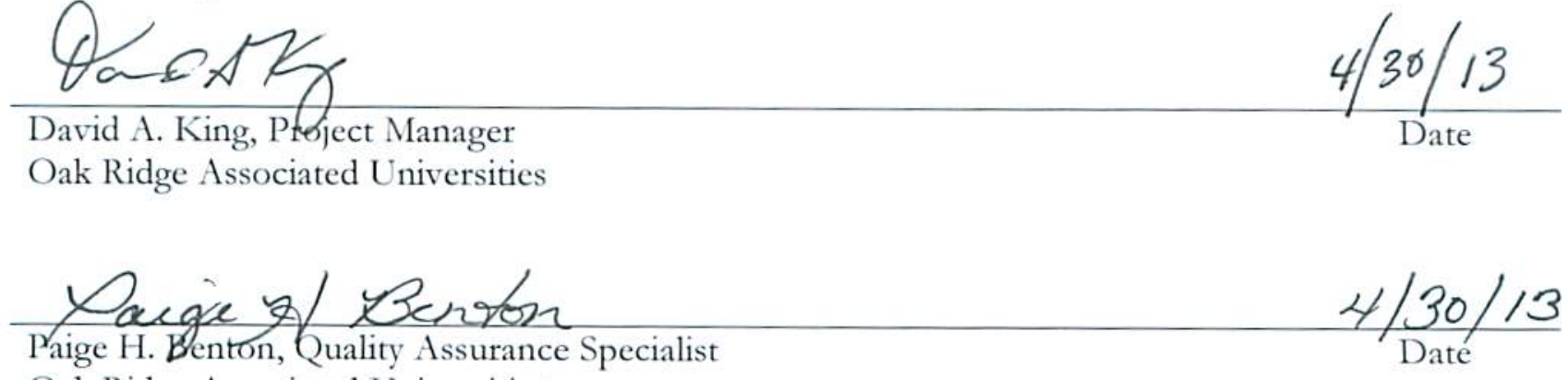

Oak Ridge Associated Universiries

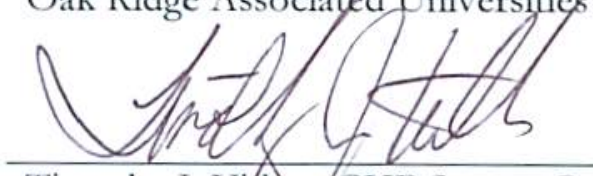

Timothy J. Vikkus.CHP Survey Operations Director

Oak Ridge Associated Universities 
THIS PAGE INTENTIONALLY LEFT BLANK 


\section{ORMU}

CONTENTS

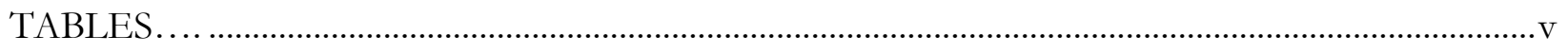

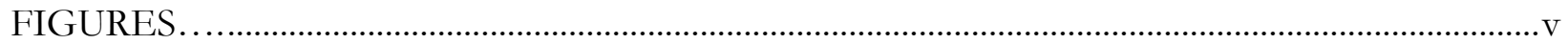

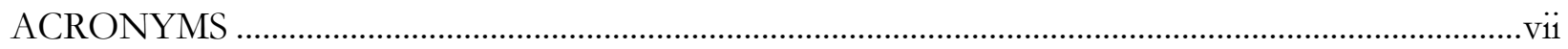

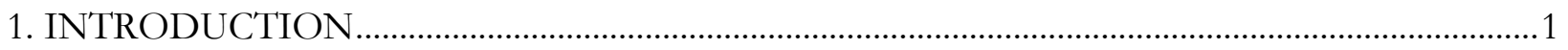

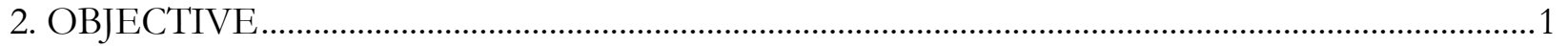

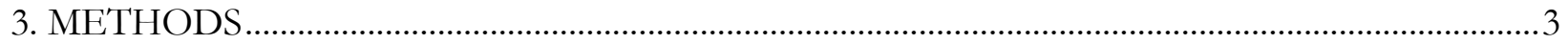

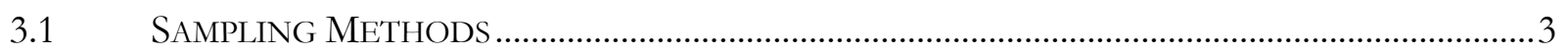

3.2 ANALYTICAL METHODS.................................................................................................

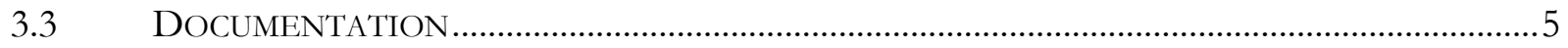

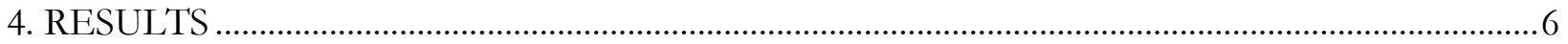

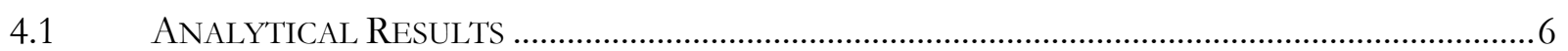

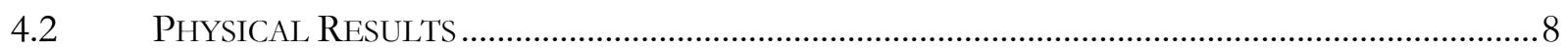

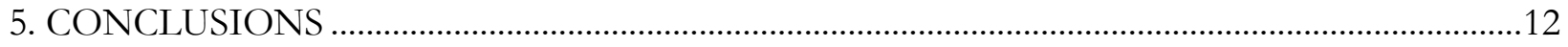

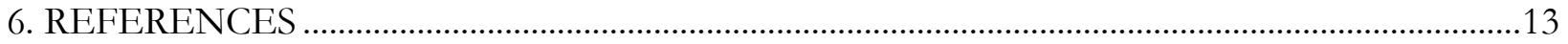




\section{TABLES}

Table 2.1. Description of Original Containers and 2010 Sampling Distribution....................................2

Table 3.1. Sample Collection Method Summary …................................................................................

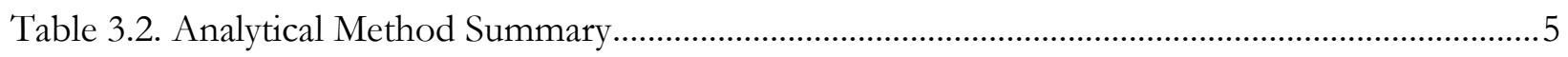

Table 4.1. Drum and Sample Container Labels Crosswalk ......................................................................6

Table 4.2. Comparison on 2010 and 2013 PCBs Concentrations ..........................................................

Table 4.3. Comparison on 2010 and 2013 Gross Alpha/Beta Concentrations......................................8

Table 4.4. Comparison on 2010 and 2013 Oils by Physical Characteristics .......................................... 9

\section{FIGURES}

Fig. 3.1. COLIWASAs Used to Sample IMPACT Services Containers ...................................................3

Fig. 3.2. IMPACT Oil Drums Staged and Ready for Sampling .............................................................

Fig. 4.1. Photographs of 2013 Samples by Original Drum Number......................................................10

Fig. 4.2. Photographs for Comparing 2010 and 2013 Oils.................................................................11 


\section{ACRONYMS}

$\begin{array}{ll}\text { ASTM } & \begin{array}{l}\text { American Society for Testing and Materials } \\ \text { COC }\end{array} \\ \text { cOLin of custody } \\ \text { DOE } & \text { composite liquid waste sampler } \\ \text { DOE-EM } & \text { U.S. Department of Energy } \\ \text { DOE-ORO } & \text { U.S. Department of Energy-Oak Ridge Office } \\ \text { EPA } & \text { U.S. Environmental Protection Agency } \\ \text { ID } & \text { identification number } \\ \text { LSRS } & \text { LATA Sharp Remediation Services } \\ \text { MCLinc } & \text { Materials and Chemistry Laboratory, Inc. } \\ \text { MDA } & \text { minimum detectable activity } \\ \text { MDL } & \text { method detection limit } \\ \text { ORAU } & \text { Oak Ridge Associated Universities } \\ \text { ORISE } & \text { Oak Ridge Institute for Science and Education } \\ \text { PCB } & \text { polychlorinated biphenyls }\end{array}$




\section{RESULTS FROM THE INDEPENDENT SAMPLING AND ANALYSIS OF USED OIL AT THE IMPACT SERVICES FACILITY IN OAK RIDGE, TENNESSEE}

\section{INTRODUCTION}

The U.S. Department of Energy (DOE) requested that Oak Ridge Associated Universities (ORAU), via the Oak Ridge Institute for Science and Education (ORISE) contract, perform independent sampling and analysis of used oils contained within eight 55 gallon drums stored at the former IMPACT Services facility, located at the East Tennessee Technology Park in Oak Ridge, Tennessee. These drums were originally delivered by LATA Sharp Remediation Services (LSRS) to IMPACT Services on January 11, 2011 as part of the Bldg. K-33 demolition project, and the drums plus contents should have been processed as non-hazardous non-radiological waste by IMPACT Services. LSRS received a certificate of destruction on August 29, 2012 (LSRS 2012a). However, IMPACT Services declared bankruptcy and abandoned the site later in 2012, and eight of the original eleven K-33 drums are currently stored at the facility. The content of these drums is the subject of this investigation. The site is currently maintained by the Tennessee Department of Environment and Conservation. Other stakeholders include, but are not limited to, the DOE Oak Ridge Office (DOE-ORO) and the DOE Office of Environmental Management (DOE-EM).

\section{OBJECTIVE}

Table 2.1 presents a summary of subject materials originally sampled in December 2010 and delivered to IMPACT Services for processing in January 2011. Only eight of the original eleven drums remain - it is presumed oils from the missing Drums K-33-NR-OIL-003, -005, and -010 were fully processed per the disposal agreement. Of the eight remaining drums, three originally contained gear oil from eleven 40-ton cranes, one contained gear oil from seven 10-ton cranes, and four contained hydraulic oils from one elevator (LSRS 2010, 2012b). The original drum contents were sampled by LSRS in 2010 and analyzed for gross alpha, gross beta, and polychlorinated biphenyls (PCBs), using both compositing and grab sampling techniques (see appendix A). The objective of this 2013 sample and analysis effort was to duplicate, to the extent possible, the 2010 sampling and analysis event to support final disposition decisions. Part of that decision process includes either 
verifying or refuting the assertion that oils that are currently stored in drums at the IMPACT

Services facility originated from Bldg. K-33 equipment.

\section{Table 2.1. Description of Original Containers and 2010 Sampling Distribution}

\begin{tabular}{|c|c|c|c|c|c|}
\hline $\begin{array}{c}\text { Original } \\
\text { K-33 Source }\end{array}$ & Gallons & $\begin{array}{c}\text { Medium } \\
\text { Description }\end{array}$ & $\begin{array}{c}2010 \\
\text { Sample }\end{array}$ & $\begin{array}{c}\text { Original Drum } \\
\text { ID }\end{array}$ & $\begin{array}{c}2013 \text { Drum } \\
\text { Location }\end{array}$ \\
\hline 40 Ton Crane 1 & 24 & \multirow{11}{*}{$\begin{array}{l}\text { Brown/black } \\
\text { gear oil }\end{array}$} & \multirow[t]{11}{*}{ Composite } & \multirow{11}{*}{$\begin{array}{l}\text { K-33-NR-OIL-001 } \\
\text { K-33-NR-OIL-002 } \\
\text { K-33-NR-OIL-003 } \\
\text { K-33-NR-OIL-004 }\end{array}$} & \multirow{11}{*}{$\begin{array}{l}\text { IMPACT } \\
\text { IMPACT } \\
\text { Unknown } \\
\text { IMPACT }\end{array}$} \\
\hline 40 Ton Crane 2 & 20 & & & & \\
\hline 40 Ton Crane 3 & 22 & & & & \\
\hline 40 Ton Crane 4 & 18 & & & & \\
\hline 40 Ton Crane 5 & 29 & & & & \\
\hline 40 Ton Crane 6 & 7 & & & & \\
\hline 40 Ton Crane 7 & 19 & & & & \\
\hline 40 Ton Crane 8 & 33 & & & & \\
\hline 40 Ton Crane 9 & 25 & & & & \\
\hline 40 Ton Crane 10 & 30 & & & & \\
\hline 40 Ton Crane 11 & 23 & & & & \\
\hline 25 Ton Crane 1 & 3 & \multirow{3}{*}{$\begin{array}{l}\text { Brown/black } \\
\text { gear oil }\end{array}$} & \multirow[t]{3}{*}{ Grab } & \multirow[t]{3}{*}{ K-33-NR-OIL-005 } & \multirow[t]{3}{*}{ Unknown } \\
\hline 25 Ton Crane 2 & 3 & & & & \\
\hline 25 Ton Crane 3 & 3 & & & & \\
\hline 10 Ton Crane 1 & 5 & \multirow{7}{*}{$\begin{array}{l}\text { Brown/black } \\
\text { gear oil }\end{array}$} & \multirow[t]{7}{*}{ Grab } & \multirow[t]{7}{*}{ K-33-NR-OIL-006 } & \multirow[t]{7}{*}{ IMPACT } \\
\hline 10 Ton Crane 2 & 5 & & & & \\
\hline 10 Ton Crane 3 & 5 & & & & \\
\hline 10 Ton Crane 4 & 5 & & & & \\
\hline 10 Ton Crane 5 & 5 & & & & \\
\hline 10 Ton Crane 6 & 5 & & & & \\
\hline 10 Ton Crane 7 & 5 & & & & \\
\hline \multirow[t]{5}{*}{ Elevator } & \multirow[t]{5}{*}{250} & \multirow{5}{*}{$\begin{array}{l}\text { Clear } \\
\text { hydraulic oil }\end{array}$} & \multirow[t]{5}{*}{ Composite } & K-33-NR-OIL-007 & IMPACT \\
\hline & & & & K-33-NR-OIL-008 & IMPACT \\
\hline & & & & K-33-NR-OIL-009 & IMPACT \\
\hline & & & & K-33-NR-OIL-010 & Unknown \\
\hline & & & & K-33-NR-OIL-011 & IMPACT \\
\hline
\end{tabular}

Source for all but the last column is LSRS 2012b. 


\section{METHODS}

The following sections describe the field sampling and laboratory analytical methods used to collect and analyze oil samples from the eight drums stored at the IMPACT Services facility.

\subsection{SAMPLING Methods}

Samples were collected in accordance with the protocols/methods listed in Table 3.1. Samples were collected using 39-inch long, 0.5625-inch inner diameter composite liquid waste samplers (COLIWASAs) with manufacturer model number BA395C. The model BA395C is a polypropylene tube with a neoprene stopper, and internal Teflon ${ }^{\circledR}$ coating to minimize sample adherence. An example COLIWASA is shown in Fig. 3.1.

\begin{tabular}{|l|l|l|}
\hline \multicolumn{3}{|c|}{ Table 3.1. Sample Collection Method Summary } \\
\hline \multicolumn{1}{|c|}{ Source } & Reference number & \multicolumn{1}{c|}{ Description/title } \\
\hline ASTM & ASTM D 5495 & $\begin{array}{l}\text { Standard Practice for Sampling With a Composite Liquid Waste } \\
\text { Sampler (COLIWASA) }\end{array}$ \\
\hline ASTM & ASTM D 5743 & $\begin{array}{l}\text { Standard Practice for Sampling Single or Multilayered Liquids, With } \\
\text { or Without Solids, in Drums or Similar Containers }\end{array}$ \\
\hline EPA & EPA 530-D-02-002 & RCRA Waste Sampling Draft Technical Guidance \\
\hline
\end{tabular}

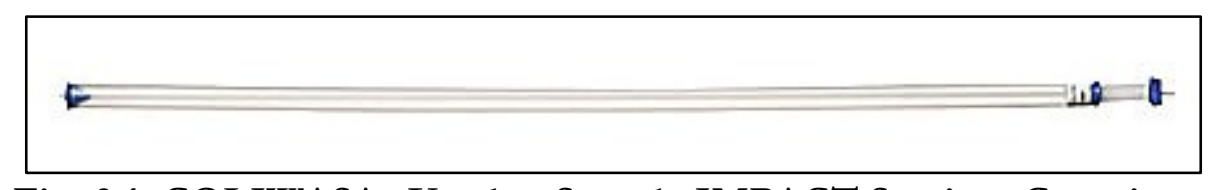

Fig. 3.1. COLIWASAs Used to Sample IMPACT Services Containers

Prior to sampling, facility operators staged drums on pallets underlain with plastic sheeting, and labeled each drum with the IMPACT Services container identification number. Facility operators also ensured that identification information was is plain sight, including the original drum identification numbers assigned by LSRS.

ORAU samplers surrounded each drum opening with plastic sheeting and absorbent pads. A new COLIWASA tube, sample container, and labels were staged on the absorbent pads of each drum prior to sampling, as shown in Fig. 3.2. Samplers wore four glove layers: inner cotton liner, inner 


\section{ORAU}

nitrile gloves, chemical resistant gloves, and outer nitrile gloves. New outer nitrile gloves were donned at each drum prior to sampling to prevent cross contamination.

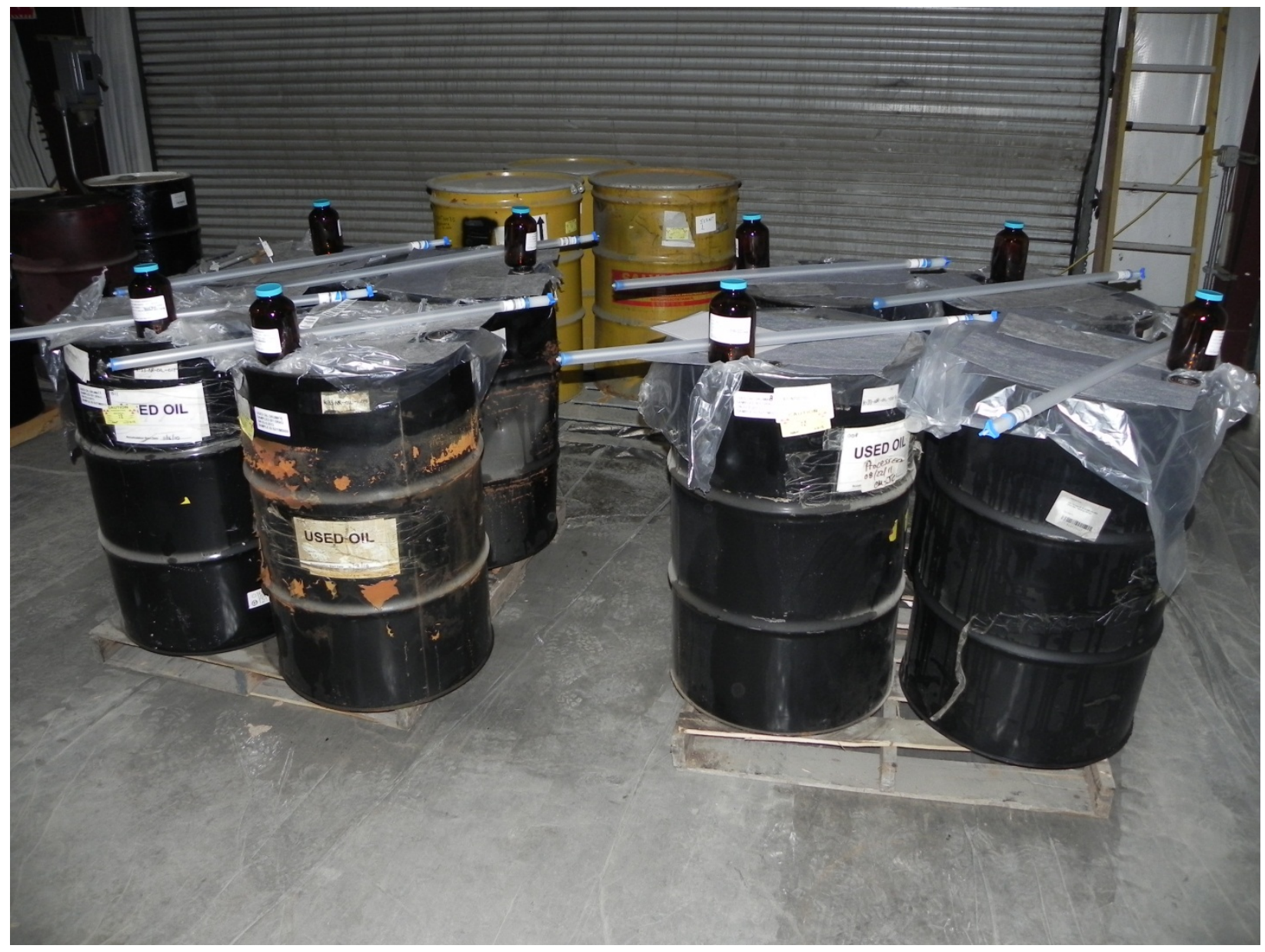

Fig. 3.2. IMPACT Oil Drums Staged and Ready for Sampling

The sampling and analysis design duplicated the approach used in 2010, though Drums K-33-NROIL-003, -005 , and -010 were not available for sampling. Sampling generally proceeded as follows:

1. One sampler slowly lowered the COLIWASA in the open position into the drum until the bottom of the container was reached.

2. The sampler stoppered the end of the COLIWASA to prevent sample loss, and slowly extracted the tube.

3. The assistant positioned a pre-cleaned $950 \mathrm{ml}$ amber glass bottle under the extracted COLIWASA, and the sampler carefully loosened the stopper - oil was then slowly dispensed into the sample bottle to minimize sample agitation. 
4. Steps 1-3 were repeated until a minimum estimated volume of $500 \mathrm{~mL}$ was collected.

5. The bottle was labeled and sealed with tamper resistant custody tape.

6. Samplers proceeded to the next drum and repeated Steps 1-5 until all drums were sampled.

7. After all samples were collected, samplers wrapped the used COLIWASAs and used gloves within the absorbent pads and plastic sheeting, then placed each bundle in a new waste container designated for that purpose.

The contents of each drum were sampled and containerized separately to allow potential future analysis of individual drum media. Increments were composited at the analytical laboratory, as appropriate.

Upon completion of sampling, each drum was affixed with an additional label reflecting the ORAU sample identification number and the date of sample collection.

\subsection{ANALYTICAL METHODS}

All compositing and laboratory analyses were performed by Materials and Chemistry Laboratory, Inc. (MCLinc) in Oak Ridge, Tennessee using the methods presented in Table 3.2. MCLinc composited increments prior to analysis to duplicate, to the extent possible, the 2010 effort. All compositing was performed on an equal volume basis. The sample from Drum K-33-NR-OIL-006 was not composited in either the 2010 or 2013 sample event.

\section{Table 3.2. Analytical Method Summary}

\begin{tabular}{|c|c|l|}
\hline Analysis & Method & \multicolumn{1}{c|}{ Method Title } \\
\hline Gross Alpha/Beta & MCL-7759 & Gross Alpha, Gross Beta Total Activity by LSC \\
\hline & SW-846 8082A & $\begin{array}{l}\text { Polychlorinated Biphenyls by Gas Chromatography } \\
\text { PCBs }\end{array}$ \\
MCL-7740 & Determination of PCBs \\
\hline
\end{tabular}

\subsection{DOCUMENTATION}

Equipment, sampling activities, and labeling/identification methods were documented by digital photography and in the project logbook. Chain of custody (COC) records including sample 
collection information and requested analyses were completed and transferred to MCLinc with the samples on the day of sampling.

All associated documentation was conducted in a manner sufficient to recreate the event without reliance on personnel memory and is capable of providing a crosswalk between samples and their source. All critical records, including the field logbook and COCs, will be retained by ORAU as part of the project file.

\section{RESULTS}

Eight discrete samples were collected and delivered under custody and in good order to MCLinc on March 5, 2013. MCLinc composited the samples at their facility, as applicable, to duplicate the 2010 sample and analysis event. The Table 4.1 crosswalk lists the original drum label, 2010 sample IDs assigned by LSRS and MCLinc, and the 2013 increment and sample IDs assigned by ORAU and MCLinc (noting MCLinc performed both the 2010 and the 2013 analyses).

\begin{tabular}{|c|c|c|c|c|}
\hline \multirow{2}{*}{$\begin{array}{c}\text { Original Drum } \\
\text { Labels }\end{array}$} & \multicolumn{2}{|c|}{2010 Sample Labels } & \multicolumn{2}{|c|}{2013 Sample Labels } \\
\hline & LSRS & MCLinc & ORAU & MCLinc \\
\hline K-33-NR-OIL-001 & K33-CRO-1C4-1 & $10-8480$ & $5211 \mathrm{M} 0006$ & $13-0519$ \\
\hline K-33-NR-OIL-002 & & & $5211 \mathrm{M} 0010$ & \\
\hline K-33-NR-OIL-003 & & & $\mathrm{N} / \mathrm{A}$ & \\
\hline K-33-NR-OIL-004 & & & $5211 \mathrm{M} 0009$ & \\
\hline K-33-NR-OIL-005 & K33-CRS-5-1 & 10-8481 & $\mathrm{N} / \mathrm{A}$ & $\mathrm{N} / \mathrm{A}$ \\
\hline K-33-NR-OIL-006 & K33-CRO-6-1 & $10-8482$ & $5211 \mathrm{M} 0012$ & $13-0476$ \\
\hline K-33-NR-OIL-007 & K33-EL-7C11-1 & $10-8483$ & $5211 \mathrm{M} 0007$ & $13-0520$ \\
\hline K-33-NR-OIL-008 & & & $5211 \mathrm{M} 0011$ & \\
\hline K-33-NR-OIL-009 & & & $5211 \mathrm{M} 0008$ & \\
\hline K-33-NR-OIL-010 & & & $\mathrm{N} / \mathrm{A}$ & \\
\hline K-33-NR-OIL-011 & & & $5211 \mathrm{M} 0013$ & \\
\hline
\end{tabular}

$\mathrm{N} / \mathrm{A}=$ not applicable; drums were not available for sampling.

\subsection{ANALYTICAL RESUlts}

Appendix A presents the analytical case narrative from the 2010 sampling event, and Appendix B presents the analytical case narrative from the 2013 sampling event. Table 4.2 presents PCB 
analytical results from the 2010 and 2013 efforts. Aroclor-1016 was the only PCB detected, and it was only detected in the 2010 gear oil and 2010 hydraulic oil composites. (Note that "Totals" in these cases are equivalent to the Aroclor-1016 values.) PCBs were not detected in any of the 2013 samples.

The fact that drum K-33-NR-OIL-003 was not included in the 2013 composite could have contributed to the difference in Composite 1 PCB results, though one would be forced to conclude that only gear oil in a crane or cranes drained into this specific drum contained PCBs at concentration of at least $13 \mu \mathrm{g} / \mathrm{g}$. The 2010 elevator hydraulic oil sample contained $2.2 \mu \mathrm{g} / \mathrm{g}$ of Aroclor-1016, but again the 2013 composite sample produced no detectable PCBs. Hydraulic oils represented by Composite 2 were drained from one elevator (LSRS 2010), thus it is unclear why there would be a difference in 2010 and 2013 values. One must conclude detectable PCBs were located only in Drum K-33-NR-OIL-010, which does not seem plausible for the presumed homogeneous medium originating from a single source. PCBs were not detected in either the 2010 or the 2013 sample from Drum K-33-NR-OIL-006.

These analytical results suggest, but do not definitively prove, that the materials represented by 2010 Composite 1 and Composite 2 are different from the materials represented by 2013 Composite 1 and Composite 2 samples. Results from Drum K-33-NR-OIL-006 are inconclusive.

\begin{tabular}{|l|ccccccccccc|}
\hline \multicolumn{10}{|c|}{ Table 4.2. Comparison on 2010 and 2013 PCBs Concentrations } \\
\hline & \multicolumn{10}{|c|}{ Aroclors $\mathbf{( m g / k g}$ or $\mathbf{~ g / g ) ~}$} \\
Sample Grouping & $\mathbf{1 0 1 6}$ & $\mathbf{1 2 2 1}$ & $\mathbf{1 2 3 2}$ & $\mathbf{1 2 4 2}$ & $\mathbf{1 2 4 8}$ & $\mathbf{1 2 5 4}$ & $\mathbf{1 2 6 0}$ & $\mathbf{1 2 6 2}$ & $\mathbf{1 2 6 8}$ & Totals & MDL \\
\hline 2010 Composite 1 & $\mathbf{1 3}$ & 0.90 & 0.90 & 0.90 & 0.90 & 0.90 & 0.90 & 0.90 & 0.90 & $\mathbf{1 3}$ & 0.90 \\
2013 Composite 1 & $\mathbf{0 . 9 8}$ & 0.98 & 0.98 & 0.98 & 0.98 & 0.98 & 0.98 & 0.98 & 0.98 & $\mathbf{0 . 9 8}$ & 0.98 \\
\hline 2010 Composite 2 & $\mathbf{2 . 2}$ & 0.89 & 0.89 & 0.89 & 0.89 & 0.89 & 0.89 & 0.89 & 0.89 & $\mathbf{2 . 2}$ & 0.89 \\
2013 Composite 2 & $\mathbf{0 . 9 9}$ & 0.99 & 0.99 & 0.99 & 0.99 & 0.99 & 0.99 & 0.99 & 0.99 & $\mathbf{0 . 9 9}$ & 0.99 \\
\hline 2010 K-33-NR-OIL-006 & 0.86 & 0.86 & 0.86 & 0.86 & 0.86 & 0.86 & 0.86 & 0.86 & 0.86 & 0.86 & 0.86 \\
2013 K-33-NR-OIL-006 & 0.92 & 0.92 & 0.92 & 0.92 & 0.92 & 0.92 & 0.92 & 0.92 & 0.92 & 0.92 & 0.92 \\
\hline
\end{tabular}

Bold added for emphasis

MDL $=$ method detection limit

Table 4.3 presents gross alpha and gross beta analytical results from the 2010 and 2013 efforts.

Gross alpha activity was not detected in any of the 2010 samples, but low level detections are reported in the 2013 Composite 1 (3.3 pCi/g) and drum K-33-NR-OIL-006 (4.1 pCi/g) samples. Conversely, gross beta was detected in 2010 Composite $1(\sim 15 \mathrm{pCi} / \mathrm{g})$ and Composite 2 
(7.12 pCi/g) but not in any 2013 sample. Gross alpha and gross beta results suggest, but do not definitively prove, that there is a difference in the material constituents represented by 2010 and 2013 samples.

\begin{tabular}{|l|cc|cc|}
\hline \multicolumn{2}{|c|}{ Table 4.3. Comparison on 2010 and 2013 Gross Alpha/Beta Concentrations } \\
\hline \multirow{2}{*}{ Sample Grouping } & \multicolumn{2}{|c|}{ Gross Alpha (pCi/g) } & \multicolumn{2}{c|}{ Gross Beta (pCi/g) } \\
Result & MDA & Result & MDA \\
\hline 2010 Composite 1 & $0.08 \pm 0.10$ & 5.20 & $14.82 \pm 1.29$ & 5.23 \\
2013 Composite 1 & $3.3 \pm 1.9$ & 3.0 & $-5.2 \pm 3.4$ & 5.9 \\
\hline 2010 Composite 2 & $-0.88 \pm 0.23$ & 2.81 & $7.12 \pm 0.66$ & 2.85 \\
2013 Composite 2 & $1.1 \pm 2.1$ & 3.4 & $-9.1 \pm 3.8$ & 6.7 \\
\hline 2010 K-33-NR-OIL-006 & $-1.26 \pm 0.39$ & 5.59 & $-5.87 \pm 0.84$ & 5.64 \\
2013 K-33-NR-OIL-006 & $4.1 \pm 1.8$ & 2.8 & $-8.3 \pm 3.1$ & 5.4 \\
\hline
\end{tabular}

$\mathrm{MDA}=$ minimum detectable activity

The differences between the 2010 and corresponding 2013 concentrations of PCBs, gross alpha, and gross beta are noteworthy. Specifically, PCBs and gross alpha activity were detected in the two 2010 composite samples but in neither of the 2013 composites, and gross beta activity was not detected in any 2010 sample but was detected in two 2013 samples. In fact there is no case where an analyte was detected in both the 2010 and the corresponding 2013 samples.

\subsection{Physical Results}

Table 4.4 presents a physical description of subject materials based on LSRS documents and observations from the 2013 sampling events. ORAU's 2013 volume estimates are based on visual inspection during sampling and are rounded to the nearest 5 gallons. Figure 4.1 presents pictures of oils extracted from each drum during the 2013 event. Figure 4.2 presents the same extracted oils in one frame plus example hydraulic and gear oil samples provided by LSRS (2013). The examples are provided to represent the materials as they were drummed in 2010.

The most obvious physical difference is noted when comparing oil colors from Drums K-33-NR-OIL-001, 002, 004, and 006. Specifically, all oils from these drums were described by LSRS as brown/black gear oil (LSRS 2012b). Oils found during the 2013 event were light brown to amber for Drums K-33-NR-OIL-001 through 004 (Composite 1), and the 2013 sample from 


\section{ORMU}

K-33-NR-OIL-006 was red. Color differences in Composite 2 materials are less striking, though the 2013 increment from Drum K-33-NR-OIL-011 is noticeably darker from the other increments.

Table 4.4. Comparison on 2010 and 2013 Oils by Physical Characteristics

\begin{tabular}{|c|c|c|c|c|c|c|}
\hline \multirow[b]{2}{*}{ Original Drum ID } & \multicolumn{2}{|c|}{ Physical Description } & \multicolumn{4}{|c|}{ Drum Volume (gal) } \\
\hline & 2010 & 2013 & $2010^{a}$ & $2013^{b}$ & $\Delta$ & $(\%)$ \\
\hline K-33-NR-OIL-001 & Brown/black gear oil & Light Brown Amber & 53 & 30 & 23 & $57 \%$ \\
\hline K-33-NR-OIL-002 & Brown/black gear oil & Light Brown Amber & 55 & 55 & 0 & $100 \%$ \\
\hline K-33-NR-OIL-004 & Brown/black gear oil & Light Brown Amber & 55 & 40 & 15 & $73 \%$ \\
\hline K-33-NR-OIL-006 & Brown/black gear oil & Red & 37 & 30 & 7 & $81 \%$ \\
\hline K-33-NR-OIL-007 & Clear hydraulic oil & Straw colored & 48 & 40 & 8 & $83 \%$ \\
\hline K-33-NR-OIL-008 & Clear hydraulic oil & Straw colored & 50 & 30 & 21 & $59 \%$ \\
\hline K-33-NR-OIL-009 & Clear hydraulic oil & Straw colored & 55 & 55 & 0 & $100 \%$ \\
\hline K-33-NR-OIL-011 & Clear hydraulic oil & Straw colored & 23 & 15 & 8 & $65 \%$ \\
\hline
\end{tabular}

${ }^{a}$ Reported by weight by LSRS (2012b); converted to gallons by ORAU for this report

bBased on visual inspection during the March 5 sampling event; rounded to the nearest 5 gallons

$\Delta=2010$ volume -2013 volume (gallons)

$\%=$ percent of the 2010 volume found in the drums in 2013; 2013 value $\div 2010$ value

The volumes reported in 2010 drums are also different from those found in several of the drums sampled in 2013, as presented in Table 4.4. Most striking are the differences in Drums K-33-NROIL-001 and -008, each showing an estimated $20+$ gallon volume reduction-approximately $60 \%$ of the original amount. The volume of oil contained in Drums K-33-NR-OIL-001, -004, -006, -007, -008 , and -011 in 2013 is less than those reported for the same drums in 2010. Only Drums K-33NR-OIL-007 and -009 were found with the same oil volume.

The difference in physical characteristics strongly suggested the current contents of Drums K-33-NR-OIL-001, -002, -004, and -006 are different from those sampled in 2010 and delivered to IMPACT Services in 2011. This is supported by the volume discrepancies in Drums K-33-NR-OIL001, -004, and -006. Color differences in Drums K-33-NR-OIL-007, -008, -009, and -011 are not apparent, though the color from -011 is slightly darker from other increments. The most significant 2010-to-2013 volume discrepancies are for Drums K-33-NR-OIL-001 and -008, each containing in 2013 approximately $60 \%$ of the volumes reported in 2010 . 


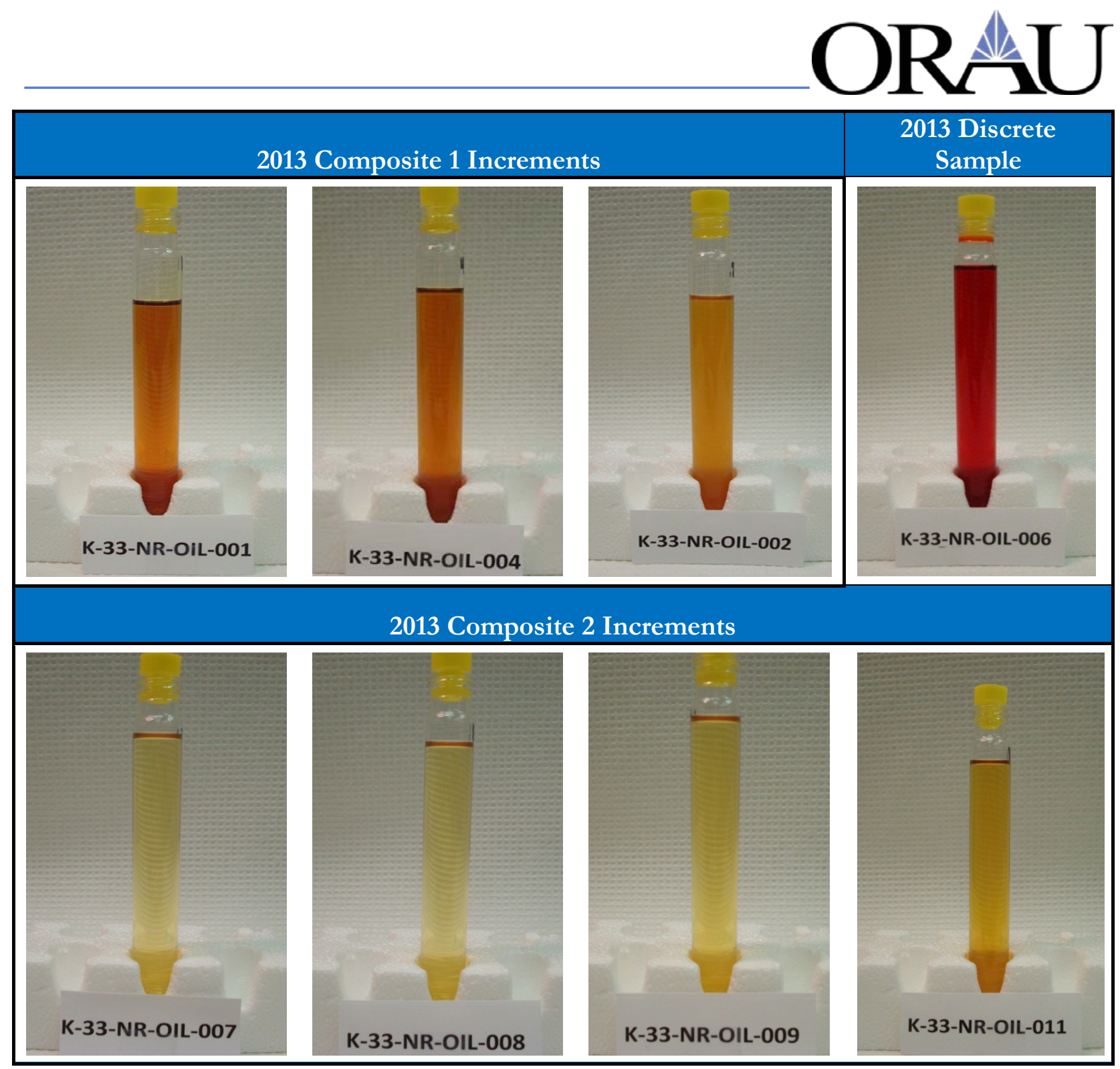

Fig. 4.1. Photographs of 2013 Samples by Original Drum Number 


\section{ORAU}

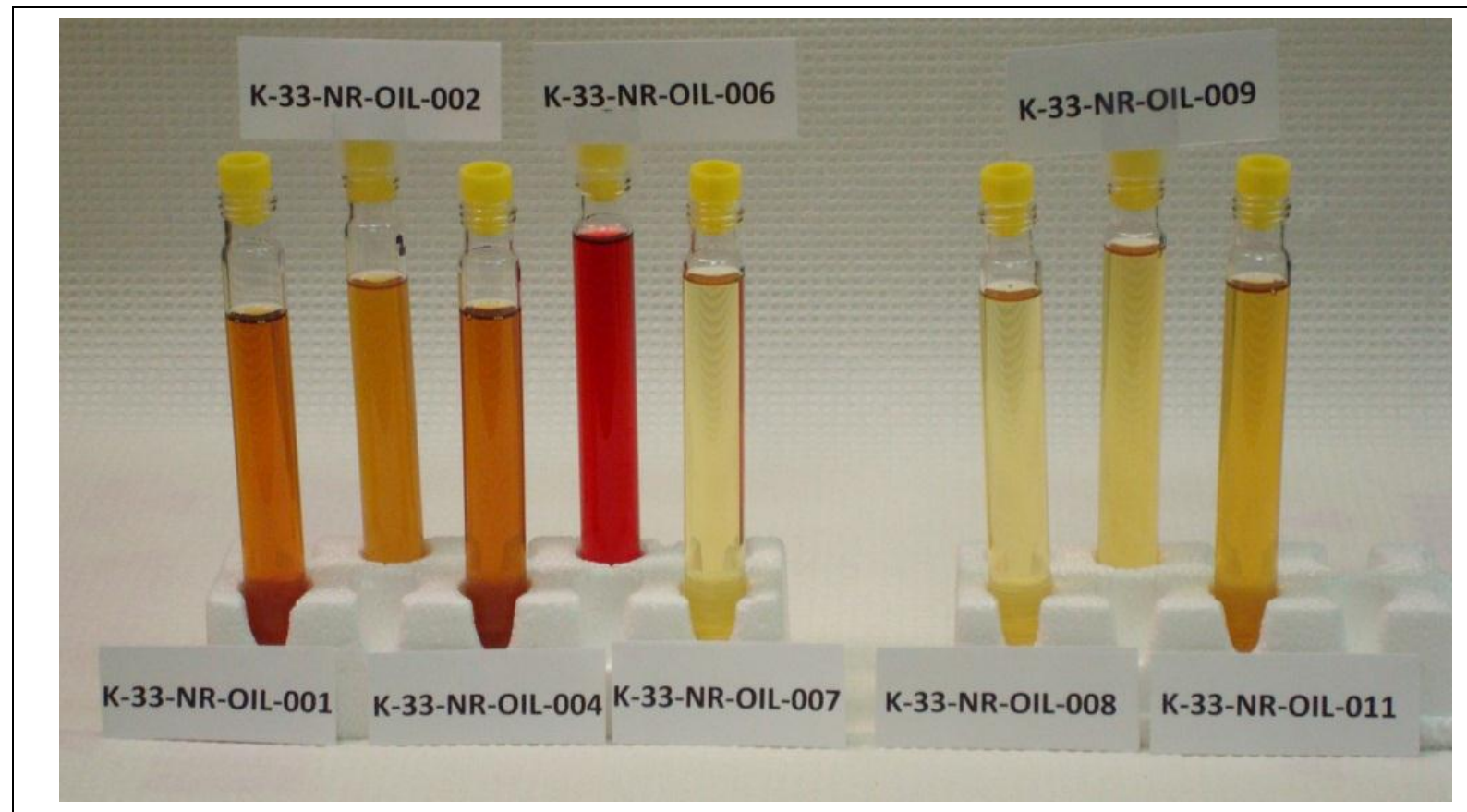

Photograph of 2013 Samples by Original Drum Number

\section{Hydraulic Oil \\ Gear Oil}

Photograph of Example Oils from the 2010 Sample Event (LSRS 2013)

Fig. 4.2. Photographs for Comparing 2010 and 2013 Oils 


\section{CONCLUSIONS}

The March 5, 2013 sampling event was conducted to support waste disposition decisions for eight drums of oil stored at the former IMPACT Services facility, and to verify or refute the assertion that subject oils originated from Bldg. K-33. Samples were collected from each drum by ORAU, then composited and analyzed by MCLinc to duplicate the 2010 sampling event. Findings are summarized as follows:

- Low levels of PCBs were detected in both of the 2010 composite oils samples $(2.2 \mathrm{mg} / \mathrm{kg}$, $13 \mathrm{mg} / \mathrm{kg}$ ), whereas PCBs were not detected in any 2013 oil sample

- Low levels of gross beta activity were detected in both of the 2010 composite oils samples (14.82 pCi/g, 7.12 pCi/g), whereas gross beta activity was not detected in any 2013 oil sample

- Low levels of gross alpha activity were not detected in any 2010 sample, whereas low level gross alpha activity was detected in two 2013 samples $(3.3 \mathrm{pCi} / \mathrm{g}, 4.1 \mathrm{pCi} / \mathrm{g}$ )

(Analytical results for PCBs, gross alpha, and gross beta show low-level detection discrepancies that suggest, but do not definitively prove, that oils ORAU sampled in 2013 are different than oils LSRS sampled in 2010 and delivered to IMPACT Services in 2011)

- The color differences are striking between 2010 gear oil (brown/black) and 2013 oil (light amber or red) for Drums K-33-NR-OIL-001, -002, -004, and -006

- The color differences are not significant between the 2010 hydraulic oil and 2013 oil for Drums K-33-NR-OIL-007, -008, and -009

- Color differences in 2010 hydraulic oil and 2013 oil are not striking for Drum K-33-NROIL-011, but the 2013 oils in drum -011 are clearly darker from other oils presumably drained from the same elevator

- Volumes reported for several drums delivered in 2010 are significantly different from those sampled in 2013, with a $20+$ gallon difference in the two most extreme cases (for Drums K-33-NR-OIL-001 and -008) 
In conclusion, the observed low-level contaminant and/or physical differences strongly suggest that the oils currently stored in Drums K-33-NR-OIL-001, -002, -004, and -006 are different from the crane oils LSRS originally sampled in 2010 and transferred to the IMPACT Facility in 2011. Results for Drums K-33-NR-OIL-007, -008, -009, and -011 do not clearly verify or refute the materials originated from the K-33 elevator, though there are differences in the oils sampled in 2010 and those sampled in 2013.

\section{REFERENCES}

LSRS 2010. Logbook pages recording the source and volume of Bldg. K-33 oils eventually shipped to IMPACT Services for processing. LATA Sharp Remediation Services.

LSRS 2012a. “LSRS/DOE K-33 Trip Report - Drum Inspection” by Clyde W. Gaston, K-33 D\&D Project Manager. LATA Sharp Remediation Services. October 29.

LSRS 2012b. “Source Spreadsheet 4-5-12,” Excel spreadsheet containing oil sources, colors, volumes, compositing, and other data associated with waste oil drums delivered to IMPACT Services. LATA Sharp Remediation Services. April 5.

LSRS 2013. Photographs of oil provided as representing K-33 gear and elevator (hydraulic) oil delivered to IMPACT Services. LATA Sharp Remediation Services. April 8. 
APPENDIX A

2010 ANALYTICAL DATE CASE NARRATIVE 
THIS PAGE INTENTIONALLY LEFT BLANK 


\section{MPFINe}

December 21, 2010

Frank Miller

Lata Sharp Remediation Services, LLC

Certificate of Analysis

MCLinc Project No.: LSR002375A

Analysis of Oil Samples for PCBs and Gross Alpha/Beta

On December 15, 2010, Materials and Chemistry Laboratory, Inc. (MCLinc) received five oil samples in good condition for PCB and Gross Alpha/Beta analysis. The sampling date was identified as December 15, 2010.

For PCB analysis, the samples were prepared by MCLinc Operator Aid in MCLinc SOP MCL7756 Appendix T and analyzed by MCLinc SOP MCL-7740 (SW846-8082) by GCIECD.

Results including QC are presented in the attached tables:

The gross alpha/beta samples were prepared and analyzed per MCLinc SOP-7759 by Liquid Scintillation Counting. The results are presented in the attached tables:

All QC was acceptable.

Thank you for choosing MCLinc.

This report was reviewed and approved by:

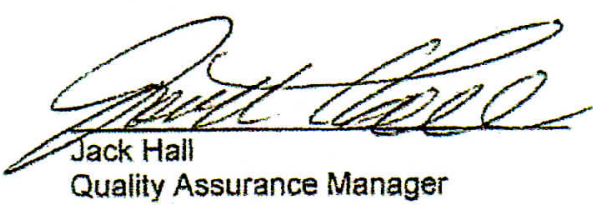

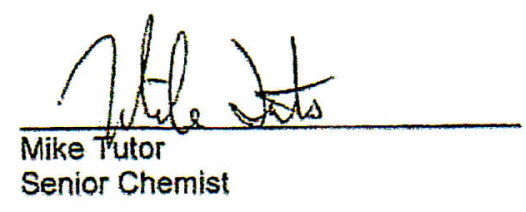

Materials and Chemistry Laboratory, Inc. East Tennessee Technology Park, Building K-100s 2010 Highway 58 , Sutte 1000

Oak Ridge Tennessee 37830.1702 Telephone: (865) $576-4138$ Fax: (855) 576-8558 www.MCL-inc.com
LSR002375A

December 21, 2010

Page 1 of 3 


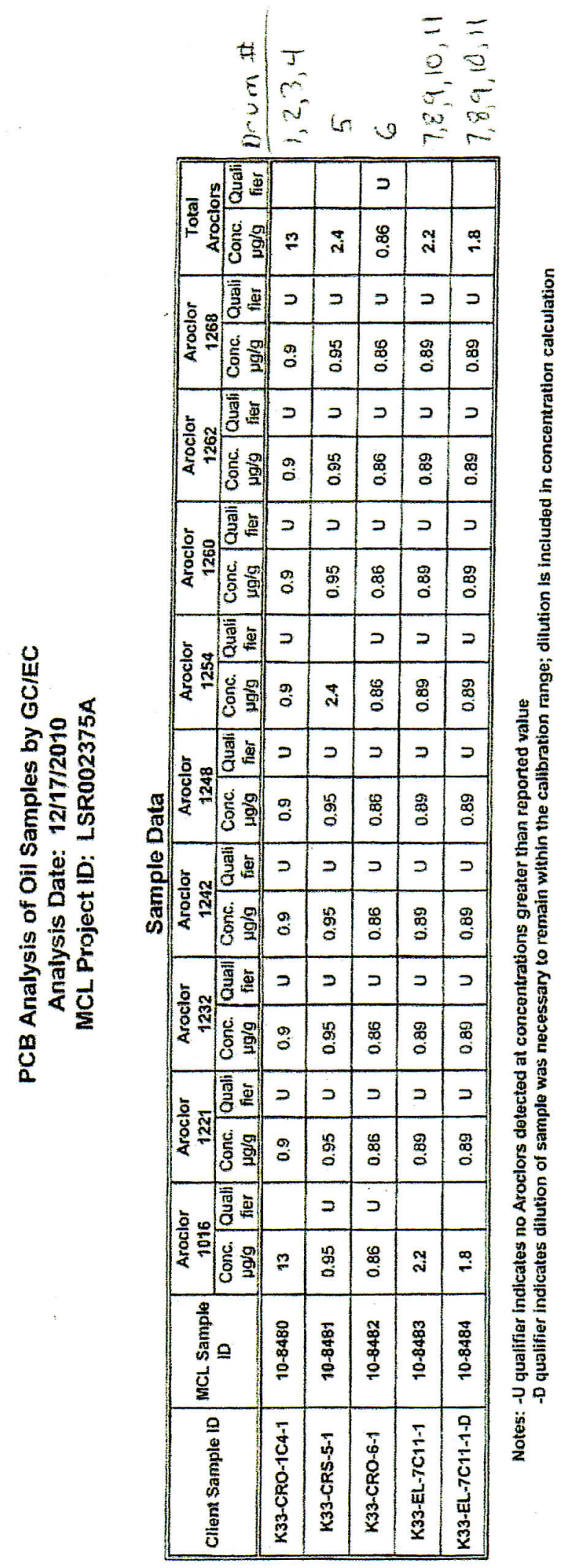

LSR002375A 
Gross Alpha/Beta Analysis by Liquid Scintillation

Analysis Date: $12 / 17 / 10$

MCL Project ID; LRS002375A

Gross Beta

\begin{tabular}{|c|c|c|c|c|c|c|}
\hline Client Sample ID & MCL Sample ID & Activity & $2 \sigma$ & MDA & Qualifier & Units \\
\hline K33-CRO-1CA-1 & $10-8480$ & 14.82 & 1.29 & 5.23 & & DCi/g UM \\
\hline K33-CRS-5-1 & $10-8481$ & 80.09 & 2.96 & 5.24 & & $\mathrm{pCi} / \mathrm{g}$ \\
\hline K33-CRO-5-1 & $10-8482$ & -5.87 & 0.84 & 5.64 & $\mathrm{U}$ & $\mathrm{pCi} / \mathrm{g}$ \\
\hline K33-EL-7C11-1 & $10-8483$ & 7.12 & 0.66 & 2.85 & & $\mathrm{pCi} / \mathrm{g}$ \\
\hline K33-EL-7C11-1-D & $10-8484$ & 3.60 & 0.47 & 2.88 & & $\mathrm{pCi} / \mathrm{g}$ \\
\hline
\end{tabular}

Gross Alpha

\begin{tabular}{|c|c|c|c|c|c|c|c|}
\hline Client Sample ID & MCL Sample ID & Activity & $\begin{array}{c}\text { Uncertainty } \\
2 \sigma\end{array}$ & MDA & Qualifier & Units \\
\hline K33-CRO-1C4-1 & $10-8480$ & 0.08 & 0.10 & 5.20 & $U$ & $\mathrm{pCi} / \mathrm{g}$ \\
\hline $\mathrm{K} 33-\mathrm{CRS}-5-1$ & $10-8481$ & 3.13 & 0.59 & 5.18 & $\mathrm{U}$ & $\mathrm{pCl} / \mathrm{g}$ \\
\hline $\mathrm{K} 33-\mathrm{CRO}-6-1$ & $10-8482$ & -1.26 & 0.39 & 5.59 & $\mathrm{U}$ & $\mathrm{pCi} / \mathrm{g}$ \\
\hline $\mathrm{K} 33-\mathrm{ELL}-7 \mathrm{C} 11-1$ & $10-8483$ & -0.88 & 0.23 & 2.81 & $\mathrm{U}$ & $\mathrm{pCi} / \mathrm{g}$ \\
\hline $\mathrm{K} 33-\mathrm{EL}-7 \mathrm{C} 11-1-\mathrm{D}$ & $10-8484$ & -1.41 & 0.29 & 2.83 & $\mathrm{U}$ & $\mathrm{pCl} / \mathrm{g}$ \\
\hline
\end{tabular}

Notes:

-U qualifier indicales aclivity reported is less than or equal to the MDA value.

-Decay correction has not been performed. 


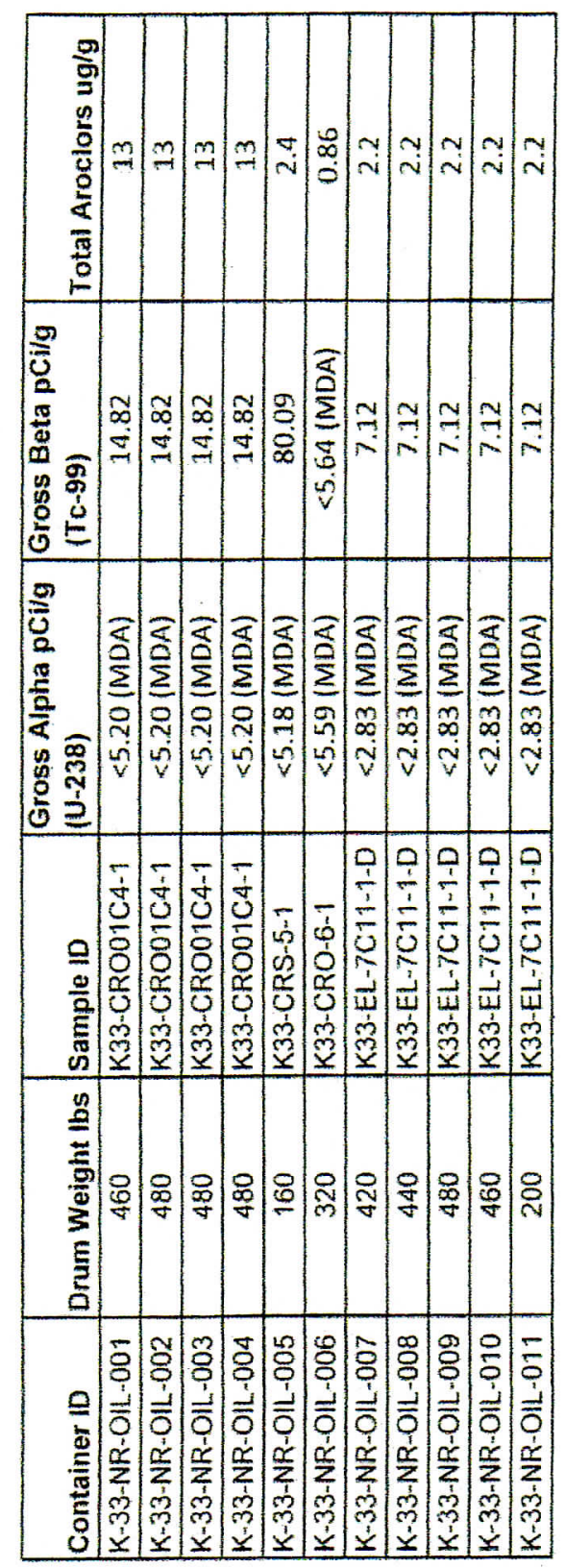




\section{APPENDIX B \\ 2013 ANALYTICAL DATE CASE NARRATIVE}

(Note: the case narrative is presented as provided by MCLinc — marked as Official Use Onlythough the data have since been approved for public release.) 
THIS PAGE INTENTIONALLY LEFT BLANK 


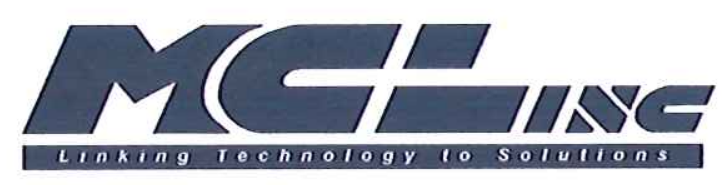

\title{
Analysis of Oil Samples from the Impact Services Site MCL Project: ORI002661A
}

\author{
Prepared for: \\ David King, ORAU \\ Independent Environmental Assessment and Verification Program \\ Oak Ridge Institute for Science and Education \\ Oak Ridge, TN 37831-0017
}

Prepared by:

Materials and Chemistry Laboratory, Inc East Tennessee Technical Park

Oak Ridge, TN 37830-1702

April 8, 2013-Rev 2

March 26, $2013-\operatorname{Rev} 1$

March 19, 2013

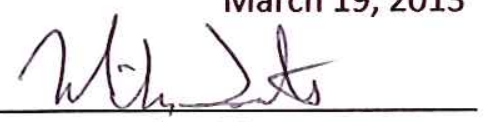

Mike Tutor, Project Manager

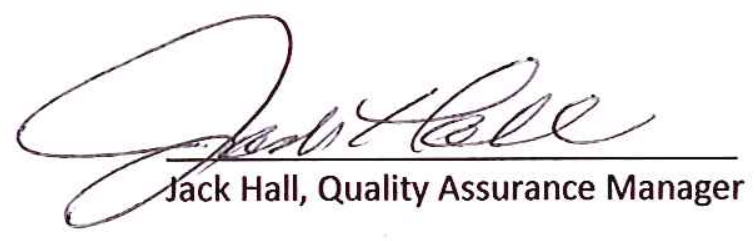

OFFICIAL USE ONLY

May be exempt from public release under the Freedom of Information Act (5, U.S.C. 552), exemption number and category: Exemption 7.

Department of Energy review required before public release.

Name/Org: $\underline{\text { J. Hall/MCL, Inc }}$

Guidance (if applicable)
Date: $\underline{3 / 19 / 13}$

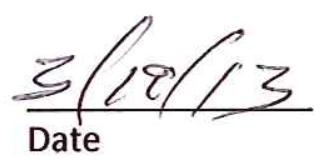




\section{Case narrative for Project ID: ORI002661A}

\subsection{Sample Receipt}

On March 5, 2013, Materials and Chemistry Laboratory (MCL) received 8 oil samples from ORISE under chain of custody (COC) number 5211030513A (See Appendix 1.) All samples were received in good condition with tamper seals intact. Each sample was assigned a unique MCL ID number. Two composite samples were generated from 7 of the samples prior to analysis. The eighth oil sample was analyzed as received. Each sample was analyzed for PCBs and gross alpha/beta activity. See Table 1 below for a summary.

Table 1

\begin{tabular}{|c|c|c|c|c|}
\hline Client Sample ID & MCLID & Composite Group & PCB & Gross a/b \\
\hline 5211M0006 & $13-0470$ & \multirow{3}{*}{$\begin{array}{l}\text { Composite Group } 1 \\
\text { (MCL ID 13-0519) }\end{array}$} & \multirow{3}{*}{$X$} & \multirow{3}{*}{$X$} \\
\hline $5211 \mathrm{M} 0010$ & $13-0474$ & & & \\
\hline 5211M0009 & $13-0473$ & & & \\
\hline $5211 \mathrm{M} 0007$ & $13-0471$ & \multirow{4}{*}{$\begin{array}{l}\text { Composite Group } 2 \\
\text { (MCL ID 13-0520) }\end{array}$} & \multirow{4}{*}{$x$} & \multirow{4}{*}{$x$} \\
\hline 5211M0011 & $13-0475$ & & & \\
\hline 5211M0008 & $13-0472$ & & & \\
\hline 5211M0013 & 13-0477 & & & \\
\hline 5211M0012 & $13-0476$ & N/A & $\mathrm{x}$ & $x$ \\
\hline
\end{tabular}

See Appendix 1 for photos.

\subsection{Gross Alpha/Beta}

Three oil samples were analyzed according to method MCL-7759, Gross Alpha, Gross Beta Total Activity by LSC. Approximately 0.2 grams of each sample was placed in a scintillation vial along with $10 \mathrm{ml}$ of Ultima Gold XR scintillation cocktail and analyzed by a liquid scintillation counter for gross alpha and gross beta activity. All quality control $(\mathrm{QC})$ measurements were acceptable. Results are presented in Table 2.

\subsection{Polychlorinated Biphenyls (PCBs)}

Three oil samples were analyzed according to methods SW 846 Method 8082A, Polychlorinated Biphenyls (PCBs) by Gas Chromatography, and MCL-7740, Determination of PCBs. Approximately 0.5 grams of each sample was diluted in hexane and analyzed by a dual column gas chromatograph equipped with an electron capture detector. All quality control (QC) measurements were acceptable. Results are presented in Table 3. 


\section{Table 2}

Gross Alpha/Beta Analysis by Liquid Scintillation

Analysis Date: 03/07/2013 Revised 3/26/2013

MCL Project ID: ORI002661A

\begin{tabular}{|c|c|c|c|c|c|c||}
\hline \multicolumn{7}{|c|}{ Gross Beta Activity } \\
\hline Client Sample ID & MCL Sample ID & Activity & $\begin{array}{c}\text { Uncertainty } \\
\mathbf{2 \sigma}\end{array}$ & MDA & Qualifier & Units \\
\hline Composite Group 1 & $13-0519$ & -5.2 & 3.4 & 5.9 & $\mathrm{U}$ & $\mathrm{pCi} / \mathrm{g}$ \\
\hline Composite Group 2 & $13-0520$ & -9.1 & 3.8 & 6.7 & $\mathrm{U}$ & $\mathrm{pCi} / \mathrm{g}$ \\
\hline 5211M0012 & $13-0476$ & -8.3 & 3.1 & 5.4 & $\mathrm{U}$ & $\mathrm{pCi} / \mathrm{g}$ \\
\hline
\end{tabular}

\begin{tabular}{||c|c|c|c|c|c|c||}
\hline \multicolumn{7}{|c|}{ Gross Alpha Activity } \\
\hline \hline Client Sample ID & MCL Sample ID & Activity & $\begin{array}{c}\text { Uncertainty } \\
2 \sigma\end{array}$ & MDA & Qualifier & Units \\
\hline Composite Group 1 & $13-0519$ & 3.3 & 1.9 & 3.0 & & $\mathrm{pCi} / \mathrm{g}$ \\
\hline Composite Group 2 & $13-0520$ & 1.1 & 2.1 & 3.4 & $\mathrm{U}$ & $\mathrm{pCi} / \mathrm{g}$ \\
\hline 5211M0012 & $13-0476$ & 4.1 & 1.8 & 2.8 & & $\mathrm{pCi} / \mathrm{g}$ \\
\hline
\end{tabular}

Notes:

$-U$ qualifier indicates activity reported is less than or equal to the MDA value.

-Decay correction has not been performed.

\begin{tabular}{||c|c|c|c|}
\hline \multicolumn{4}{|c|}{ QA/QC } \\
\cline { 2 - 4 } & \multicolumn{3}{|c|}{ LCS \% Recovery } \\
\hline & $\mathrm{pCi} / \mathrm{g}$ Measured & $\mathrm{pCi} / \mathrm{g}$ Expected & $\%$ Recovery \\
\hline Beta & 3750 & 4027 & 93 \\
\hline Alpha & 4512 & 4467 & 101 \\
\hline \multicolumn{4}{|c|}{ Duplicate \% Difference } \\
\cline { 2 - 4 } & \multicolumn{4}{|c|}{} \\
\cline { 2 - 5 } & $\mathrm{pCi} / \mathrm{g} 13-0519$ & $\mathrm{pCi} / \mathrm{g} 13-0519$ DUP & $\%$ Recovery \\
\hline Beta & -5.20 & -3.3 & 22 \\
\hline Alpha & 3.23 & 2.86 & 6 \\
\hline
\end{tabular}




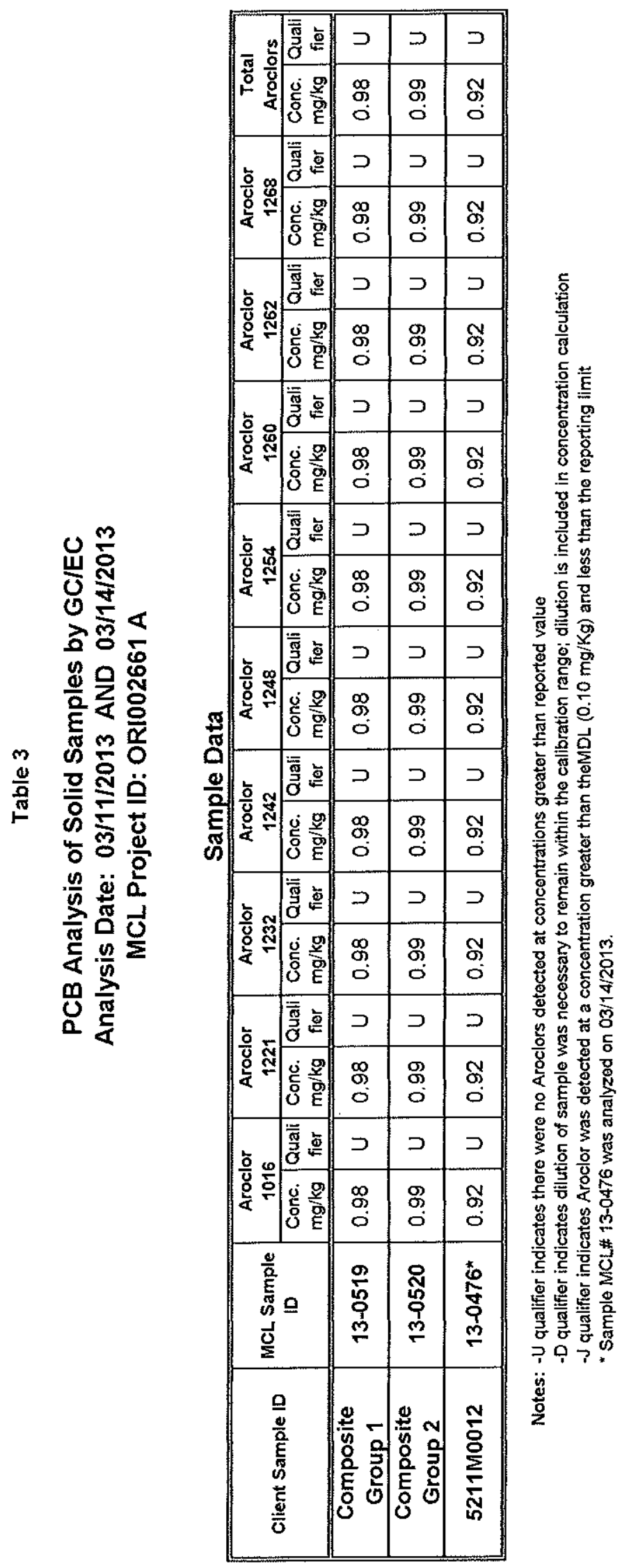




\section{Appendix 1}



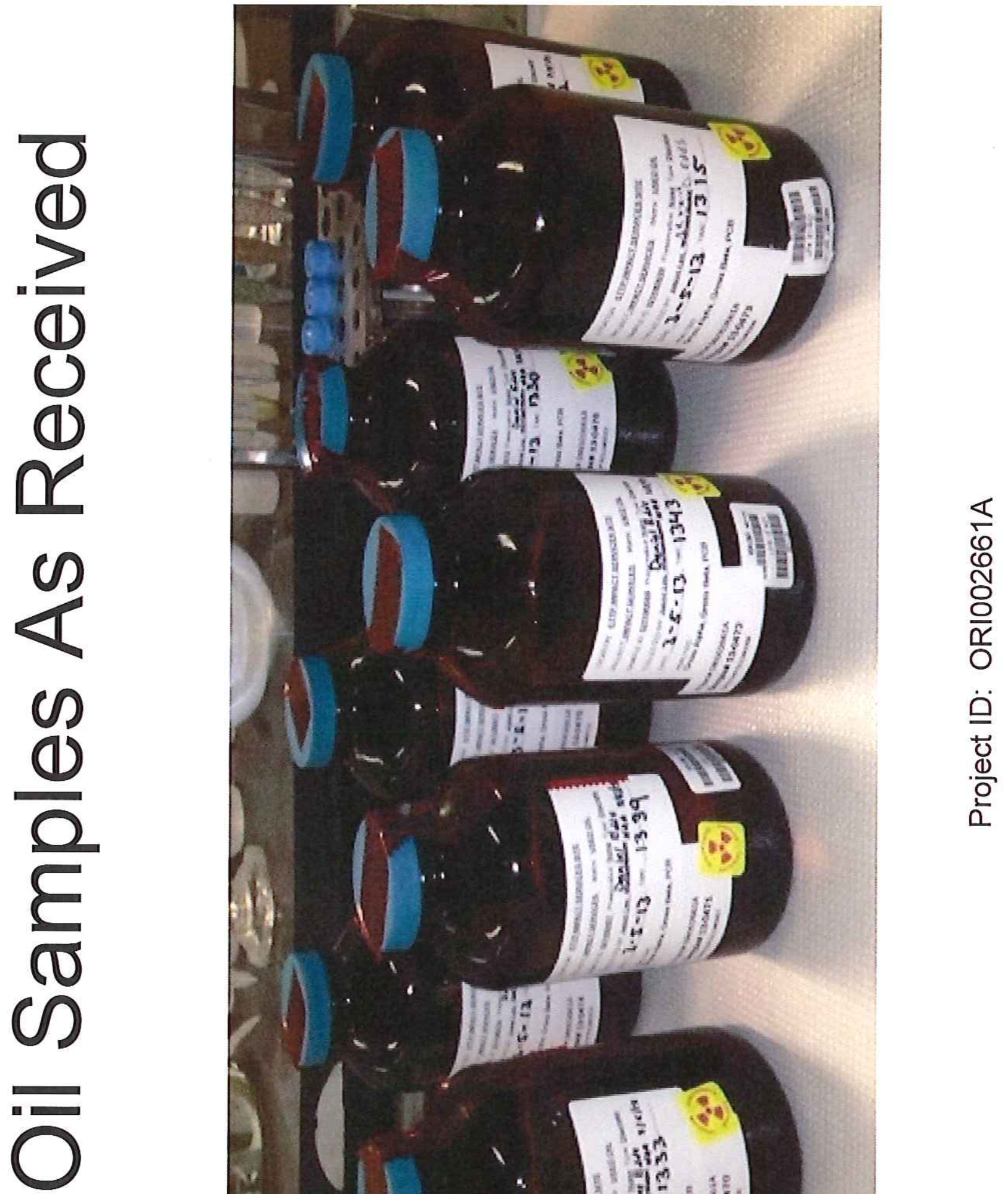
ORI002661A OIL

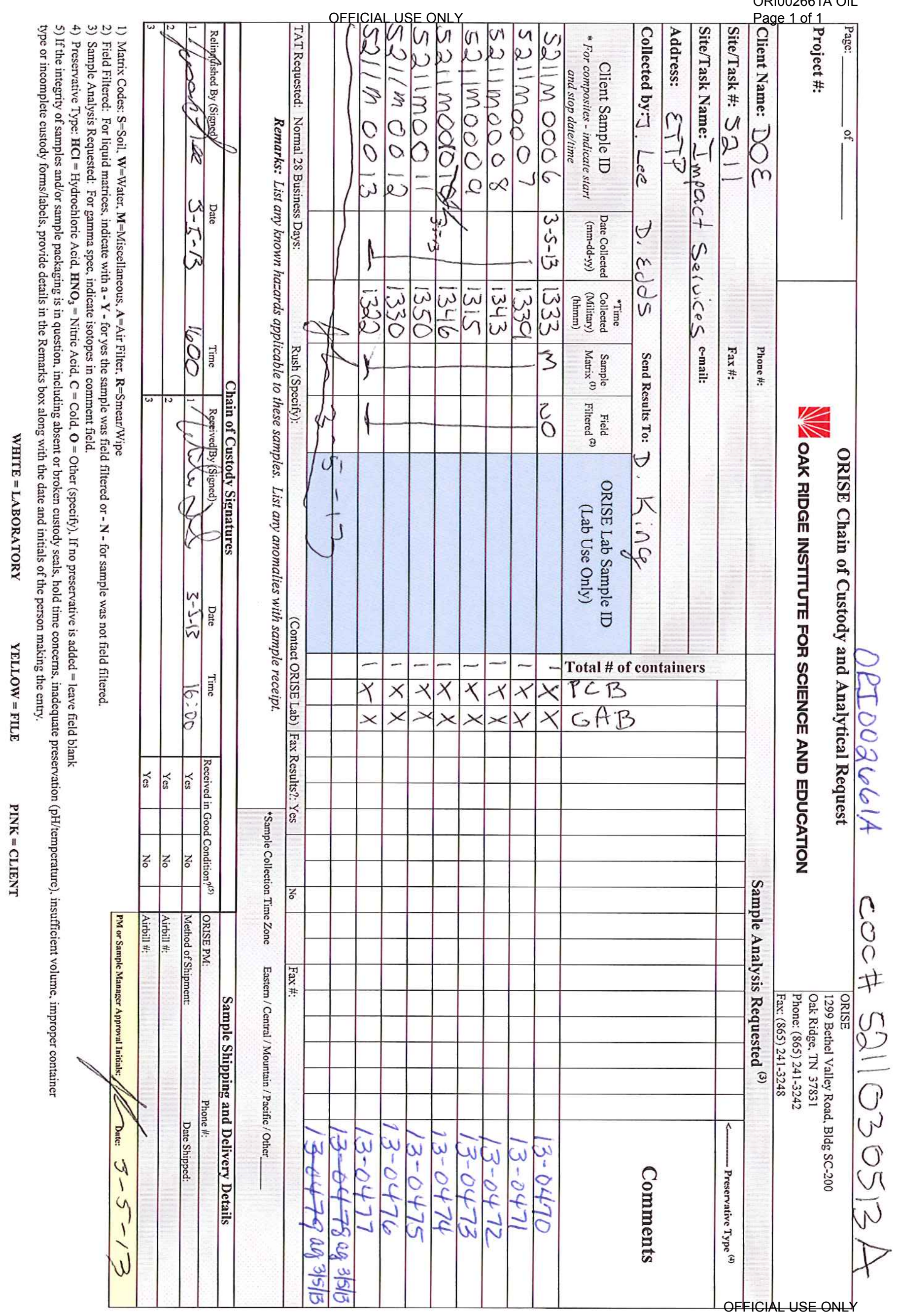


THIS PAGE INTENTIONALLY LEFT BLANK 